\title{
OSNOVNE CRTE PREDFILOZOFSKOG ISKUSTVA TEORIJE
}

Ovaj rad posvećen je ispitivanju osnovnih momenata predfilozofskog iskustva teorije. Rad pokazuje da je izvorni smisao teorije nerazdvojan od njegovog religiozno-političkog konteksta. Unutar datog konteksta izvorno iskustvo teorije se pokazuje u svojoj trostrukoj strukturi: napuštanje poznatog, putovanje i posmatranje božanskog, te povratak u poznato. Analiza pokazuje da iskustvo teorije kao specifično putovanje u strano podrazumeva određeno držanje posmatrača, a da samo posmatranje zapravo znači boravljenje unutar regije pojavljivanja božanskog koje preobražava posmatrača.

Ključne reči: teorija, svečanost, hodočašće, posmatranje, iskustvo, bog

Iskustvo teorije je neposredno vezano za viđenje božanskog. Međutim, veza posmatranja i božanskog se ne može uspostaviti prostom etimologijom reči $\theta \varepsilon \omega \rho i ́ \alpha$ (Koller, 1958: 274; Ker, 2000: 309-310; Hajdeger: 2007: 38, Elsner, Rutherford,

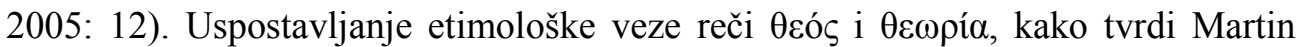
Hajdeger, pripada vremenu koje neposredno prethodi Plotinu. Takvo tumačenje nalazimo kod Aleksandra Afrodizijskog, i ono je, ističe Hajdeger, specifična aristotelijanska reinterpretacija koja ne zahvata izvorni smisao reči $\theta \varepsilon \omega \rho i ́ \alpha$ jer je određena naknadnim filozofskim razumevanjem božanskog i teorije (Heidegger, 1992: 63).

Hajdeger u razumevanju reči $\theta \varepsilon \omega \rho i ́ \alpha$, za koju kaže da ima "uzvišeno i

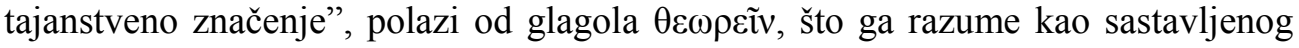
od korenskih reči $\theta \varepsilon ́ \alpha$ i ópó $\omega$. Hajdeger ukazuje na to da $\theta \dot{\varepsilon} \alpha$ znači aspekt, izgled ili vid u kojem se nešto nudi. Odatle je još i kod Platona prisutna živa veza sa izvornim značenjem $\theta \varepsilon \omega \rho \varepsilon i v$, jer izgled u kojem se nešto daje jeste $\varepsilon$ ĩ $\delta o \varsigma$, a to da je izgled

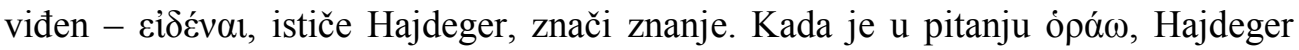

*nikolatatalovic@ff.uns.ac.rs 
kaže da data korenska reč znači pogledati, razgledati, posmatrati nešto. U krajnjem,

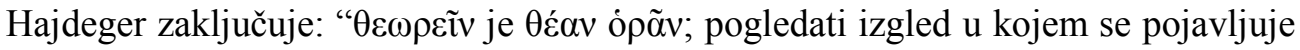
ono što je prisutno, i posredstvom takvog gledanja prebivati, gledajući, kod onoga što je prisutno" (Hajdeger, 1999: 38). Pored prethodnog, Hajdeger ističe da grčka reč ópó $\omega$ znači "obzir koji imamo prema nekom ili nečem, čast koju nekom ili nečem ukazujemo i pažnju koju nekom ili nečem poklanjamo" (Hajdeger, 1999: 38). U pogledu na analizu značenja korenskih reči Hajdeger određuje prvobitni smisao $\theta \varepsilon \omega \rho i ́ \alpha$-e kao "poštovalačku pažnju ukazanu neskrivenosti onoga što je prisutno", te kao "čuvalačko posmatranje istine" (Hajdeger, 1999: 38).

U saglasnosti sa Hajdegerom, Džejms Ker ističe da reč óó́ videti, već upućuje na onoga koji čuva, brine (Ker, 2000: 309). Čuvati, brinuti za nešto ovde znači ujedno održavati integritet određene sfere ili institucije. U pogledu

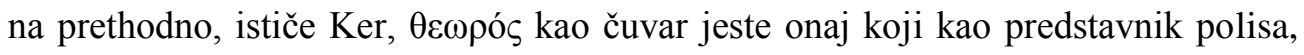
čuvajući određenu stvar, čuva integritet polisa. S obzirom na prethodno rečeno,

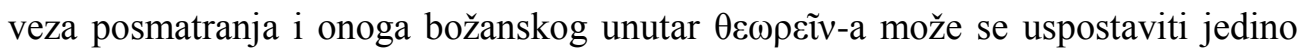
analizom samog fenomena $\theta \varepsilon \omega \rho i ́ \alpha-e$, koji je nerazdvojan od svog religioznopolitičkog konteksta i to je upravo pravac koji ćemo mi slediti.

Sam fenomen teorije izrasta iz načina na koji je funkcionisao polis, stoga se predfilozofski smisao teorije ne može zahvatiti nezavisno od svog religioznopolitičkog konteksta koji određuje svo dalje grananje datog fenomena, a pogotovo filozofsku aproprijaciju teorije od strane Platona i Aristotela, što biva odlučujuća za dalje kretanje povesti pojma teorije. Upravo je način na koji je polis stupao u odnos sa svojim drugim, tj. način na koji je opštio sa onim što je bilo van teritorije nad kojom je imao neposrednu upravu, bila $\theta \varepsilon \omega \rho i ́ \alpha$ kao "sveto izaslanstvo" putem kojeg se uspostavljalo šire jedinstvo starogrčkog naroda, u krajnjem identitet onoga biti

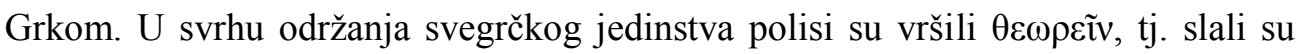
sveta izaslanstva (za šta je postojao poseban fond pod imenom $\theta \varepsilon \omega \rho$ ıóv), ${ }^{1}$ koja su

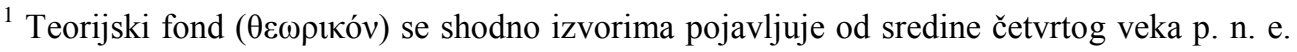

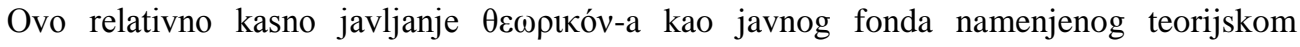
putovanju kako na lokalne tako i na inostrane svečanosti razlog je koji po Najtingejlovoj govori u prilog, nasuprot Sajmonu Goldhilu (Goldhill, 1987), da je prvobitno teorijsko putovanje podrazumevalo odlazak van teritorije koja je bila pod ingerencijom polisa. U

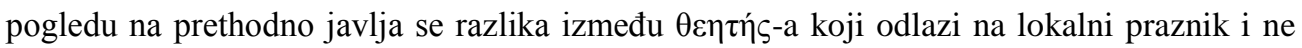

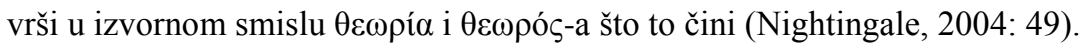




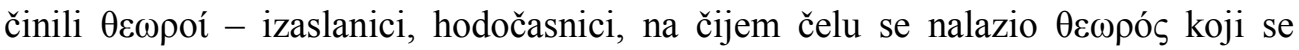

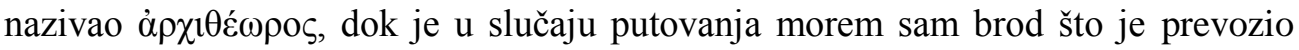
hodočasnike nosio naziv $\theta \varepsilon \omega \rho i ́ s$.

Unutar datog religiozno-političkog konteksta, Jan Raterford, u studiji posvećenoj razvoju fenomena $\theta \varepsilon \omega \rho i ́ \alpha-e$, od njenih začetaka sve do Platonove aproprijacije, razlikuje deset osnovnih pojavnih oblika $\theta \varepsilon \omega \rho i ́ \alpha-e$. Prvi i najčešći razlog teorijskog putovanja $u$ inostranstvo, po Raterfordu, bilo je učešće $u$ panhelenskim svečanostima. Drugi razlog svetog poslanstva bila je najava predstojećih svečanosti, pri čemu svetilište nije primalo posetioce, već je slalo svoju delegaciju. Treći razlog hodočašća bilo je primanje saveta od proročišta. Četvrti razlog teorijskog poslanstva bilo je i donošenje političkih odluka na prostoru zajedničkih svetilišta. Kao peto, $\theta \varepsilon \omega \rho i ́ \alpha$ je, po Raterfordu, imala i oblik posete misterijskim svetilištima zarad incijacije u kult. Šesti oblik svetog izaslanstva podrazumevao je održavanje kultnih odnosa između polisa i udaljenog svetilišta redovnim prinošenjem darova. Sedmi oblik teorije podrazumevao je redovno slanje dobara od strane kolonija polisu koji je njima vladao. Potom, osmi oblik svetog poslanstva dolazi od toga što je određen broj svetilišta bio pod ingerencijom više polisa, te su polisi slali svoje delegacije kako bi se održavale zajedničke skupštine na kojima se odlučivalo o upravljanju svetilištem. Deveti oblik svetog poslanstva

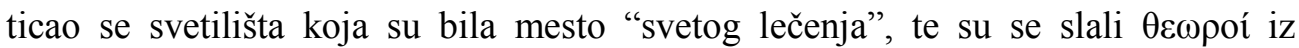
zdravstvenih razloga. Konačno, kao poslednje određenje Raterford navodi smisao

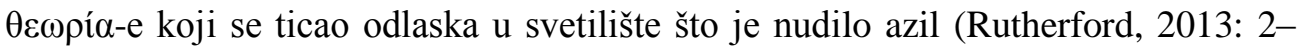
$3)^{2}$

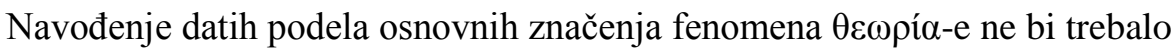
da navede na ideju da se njima samima zahvata starogrčko iskustvo $\theta \varepsilon \omega \rho i ́ \alpha-e$, već se ovim pre svega želi ukazati na bogatstvo i nesvodivost datog iskustva. To svakako ne znači da se ovde ne može uočiti svojevrsni opšti smisao, ali on se može jedino ocrtati. S obzirom na prethodno rečeno, analize koje slede pratiće pre svega $\theta \varepsilon \omega \rho i ́ \alpha-u$ u smislu hodočašća sa ciljem učestvujućeg-posmatranja svetkovine, jer se dati oblik teorije pokazuje kao odlikovani i dominatni oblik javljanja teorijskog iskustva (Rutherford, 2013: 51), preko kojeg se mogu skicirati ključni momenti teorijskog u celini, a posebno veza posmatranja i božanskog koja se etimološki ne može uspostaviti (Rausch, 1982: 16). Pored prethodnog, upravo je dati oblik teorijskog iskustva onaj koji će filozofija od vremena Platona preuzeti zarad

\footnotetext{
2 Malo drugačiji i opširiniji niz pojavnih oblika teorije nude Jaš Elsner i Raterford u zajedničkom tekstu (Elsner, Rutherford, 2005: 13-24).
} 
izgradnje vlastitog samorazumevanja nasuprot odlasku u proročište i putovanju zarad sticanja znanja kao druga dva dominatna oblika predfilozofskog iskustva teorije (Nightingale, 2004: 40).

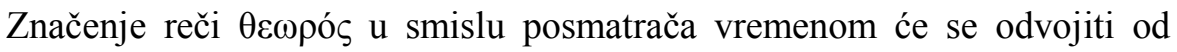
svog religiozno-političkog konteksta, te će značiti putovanje sa ciljem sticanja znanja, ali i tada će se, kao i ranije, razlikovati od uobičajene upotrebe reči $\theta \varepsilon \omega \rho \varepsilon i v$, tj. neće značiti puko posmatranje, već posmatranje božanskog kao prisustvovanje događanju istine. Na prvi pogled, čini se da je ovaj smisao teorije posebno blizak kasnijem filozofskom smislu, no videćemo da stvari stoje drugačije. Shodno datom osamostaljivanju jednog od značenja $\theta \varepsilon \omega \rho i ́ \alpha-e$, ali i u vezi sa značenjem teorije kao odlaska u udaljeno svetilište zarad inicijacije u kult ili zarad lečenja, Andrea Najtingejl uspostavlja podelu $\theta \varepsilon \omega \rho$ pía-e na "privatnu" i "civilnu". U slučaju

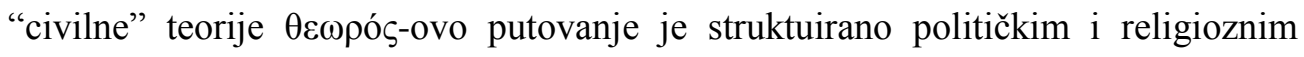
institucijama, tj. regulisano je polisom, za razliku od "privatne" ili individualne $\theta \varepsilon \omega \rho i ́ \alpha-e$, gde je $\theta \varepsilon \omega \rho o ́ \varsigma$ bio relativno slobodan i gde je, pogotovo u slučaju teorije zarad sticanja znanja, momenat odvajanja od zajednice znatno naglašeniji (Nightingale, 2004: 43, 48).

Čini se da bi kasnija filozofska aproprijacija teorije trebalo da sledi model "civilne", tj. individualne teorije kao putovanja zarad "viđenja sveta", no, kako ističe Najtingejlova, ovaj aspekt teorije filozofiji nije bio od bilo kakve koristi, naprotiv. Od vremena Platona pa nadalje, filozofija nastoji da upiše novo značenje u tradicionalni religiozno-politički smisao teorije, tj. model koji filozofija nastoji da prisvoji upravo je posmatranje religioznih svetkovina (Nightingale, 2004: 70). Naravno, ovde za nas stvar nije u tome da li filozofija, počevši od Platona, zaista dato upisivanje u prvobitni religiozno-politički smisao teorije može da sprovede bez imanentnih protivrečnosti, već da ona to čini i da je date protivrečnosti određuju.

Iako postoji suštinska razlika između "privatne" i "civilne" teorije, s obzirom na momente teorijskog putovanja, Najtingejlova uočava njihovu

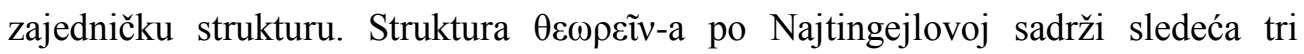
momenta: odvajanje od polisa kao mesta prebivanja (napuštanje poznatog sveta, sveta u kom se živi), liminalnu fazu samog putovanja i posmatranje religioznih svetkovina (primanja reči proroštva ili susreta sa običajima i mišljenjem stranih naroda), te povratak $\mathrm{u}$ polis određen onim što se iskusilo pri svetkovini (Nightingale, 2004: 4, 43). Data struktura očigledno upućuje na specifičnu dinamiku poznatog i stranog, odnosno teorija se uvek već odigrava kao putovanje u strano (Rausch, 1982: 23; Nightingale, 2004: 44). Međutim, ono što je suštinsko za sve navedene oblike teorije jeste neposredna veza sa zajednicom, u krajnjem sa 
fenomenom zbiranja i jedinstva. Dakle, nije moguće govoriti o teoriji bez zajedničarenja, tj. bez zajednice.

Prethodno rečeno se ne iscrpljuje u pukoj činjenici da se izvorni smisao teorije odnosio na specifičan tip prakse regulisane od strane polisa. Polis nije ono mesto koje iscrpljuje fenomen jedinstva i zajednice samo time što odlučuje o tome ko može biti $\theta \varepsilon \omega \rho o ́ \varsigma$ i zato što rukovodi načinom odvijanja teorijskog kretanja u

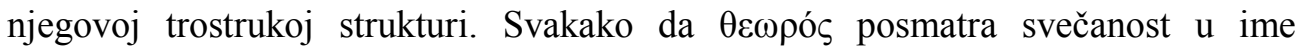
zajednice, te povratno iskustvo stranog "prevodi" na jezik polisa kojem pripada - u ovome obliku teorije posmatrač je, kako to ističe Raterford, sam polis (Rutherford, 2013: 147). ${ }^{3}$ Međutim, jedinstvo koje se ostvaruje pri posmatranju svetkovine prevazilazi granice pojedinačnog polisa i to $u$ dva osnovna smisla.

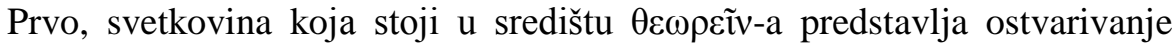
šireg jedinstva koje prevazilazi gledište pojedinačnog polisa. Upravo u skladu sa prethodnim momentom Barbara Kovalcig određuje teoriju kao: "komunalnu delatnost koja se načelno tiče stvaranja i održavanja zajednice kroz zajednički

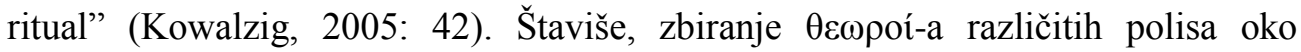
zajedničke svetkovine tek omogućava pojedinačnim polisima da povratno vide sami sebe. Drugo, mogućnost samoposmatranja koja se otvara posmatranjem svetkovine upućuje i na još jedan smisao jedinstva, naime, na učestvovanje u pojavljivanju božanskog kao onoga što zbira svaku zajednicu i daje samu mogućnost viđenja.

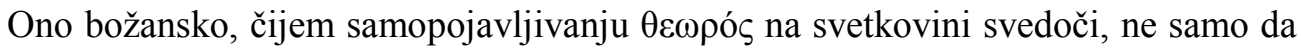
prevazilazi meru svakog pojedinačnog polisa, već božansko kao mera sama jeste ono čemu polis zahvaljuje svoju meru. Mera, red i poredak koji konstituišu zajednicu dolaze od onoga božanskog (Rausch, 1982: 24).

S obzirom na kružnu strukturu teorijskog putovanja, te vezu sa zajednicom i božanskim kao onim što zbira u jedinstvo, teorija kao hodočašće suštinski se razlikuje od čistog hođenja u strano, tj. od lutanja. Za razliku od teorijskog kretanja,

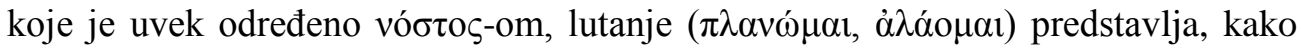
ističe Silvija Montiljo, "nestruktuirano kretanje sa one strane puta", u krajnjem, putovanje u svim pravcima - svuda i nigde (Montiglio, 2005: 2). Obe reči koje označavaju lutanje upućuju takođe i na odmetnika ili, pak, onoga što je prognan. Lutalica ( $\pi \lambda \alpha v \eta ́ \tau \eta \varsigma, \dot{\alpha} \lambda \eta ́ \tau \eta \varsigma)$ nije prosto neko ko se kreće, smatra Montiljo, već onaj ko se kreće izvan ili koji odlazi od nečega, odnosno onaj što je izbačen iz doma, zajednice. Kretanje lutanja je suštinski određeno polaznom tačkom i to $u$

\footnotetext{
${ }^{3}$ Isto ističe i Najtingejlova (Nightingale, 2004: 48).
} 
negativnom smislu, pri čemu odredište ostaje nepoznato. Time je lutanje mišljeno

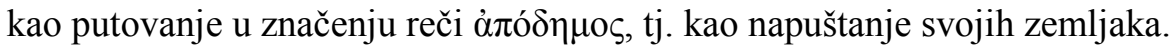

Starogrčko iskustvo lutanja najbolje sažima sam Odisej rečima: "Smrtnim

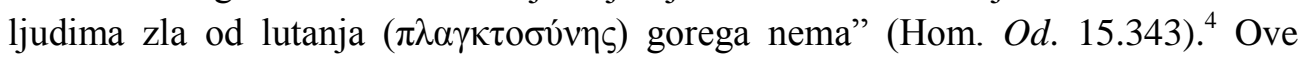
Odisejeve reči svedoče o suštinskoj razlici smrtnika i bogova. Naime, bogovi jesu oni što ih odlikuje mnogostrukost, lakoća i brzina kretanja, dok u slučaju smrtnika takvo kretanje predstavlja bol; i opšta je crta starogčkog razumevanja ludaka kao onoga što su ga bogovi izgnali iz zajednice i uma (Montiglio, 2005: 3). Takođe, u pogledu samog hodanja moguće je uspostaviti hijerahiju starogrčkog razumevanja sveta, jer je hodanje za stare Grke nerazdvojno od života. Tako su besmrtnici oni koji imaju mnogostruk, lak i brz korak, smrtne ljude određuje ograničena sposobnost hodanja u odnosu na bogove, dok mrtvi ne hodaju, već lebde kao senoviti likovi u prelaznom području podzemnog sveta (Steiner, 2001: 146-151). Lutanje kao kretanje u svim pravcima koje odlikuje ludake i bogove ukazuje na samu ambivalentnost lutanja: lutati znači znati sve i ne znati ništa. Ono što lutalica saopštava sa svojih putovanja ne može biti provereno, jer on ne pripada onome mestu gde iznosi svoju priču. Izvor priče lutalice je neodređen, nalik njegovom kretanju, što je razlog zašto se lutalica drži ujedno i lažovom i onim koji je u posedu znanja (Montiglio, 2005: 92). Upravo će ovo biti razlog zašto Platon i Aristotel, u prisvajanju izvornog smisla teorije, lutanje razumevaju samo kao početno stanje istraživanja, tj. stanje aporije koje u konačnom mora voditi strukturiranom kretanju filozofskog mišljenja. Takođe, aproprijacija teorije u smislu hodočašća od strane ova dva mislioca biće razlog zašto će u ideološkoj borbi sa sofistima istima odreći posedovanje teorije i zapravo ih razumeti kao lutalice, tj. kao one koji bez doma znaju sve, odnosno ne znaju ništa (Montiglio, 2005: 106; Nightingale, 2004: 67).

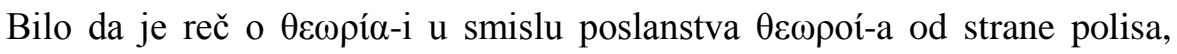
putem kojih polis sebe predstavlja drugim gradovima-državama, gradi saveze i povratno sebe reflektuje, ili pak šalje hodočasnike u proročišta zarad saveta oko bitnih pitanja koja se tiču njegove sudbine, bilo da je u pitanju individualna $\theta \varepsilon \omega \rho i ́ \alpha$ kao hodočašće zarad inicijacije u kult, zarad lečenja u svetilištu ili sa ciljem sticanja znanja, u svakom od pojavnih oblika prisutna je veza sa onim božanskim. Stupanje u odnos sa onim božanskim podrazumeva nekoliko ključnih momenata.

Kao prvo, stupanje u odnos sa onim božanskim, posmatrano uopšte, podrazumeva specifičan način držanja onoga koji stupa u dati odnos, podrazumeva primeren $\varepsilon^{\prime} \theta$ os (Rausch, 1982: 28). Tako u religiozno-političkom smislu polis šalje

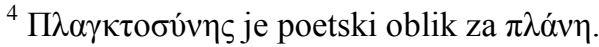


samo one koji ga dostojno mogu predstavljati na svečanosti ili one što nose poverenje polisa da će verno preneti reči proročišta zajedici, kako bi ista o smislu date naznake vodila interpretativni dijalog i donela konačnu odluku u pogledu ključnih pitanja. Raskrivanje božanskog unutar svetkovine ili saveta proročišta pokazuje se kao poseban tip iskustva, koji, po Raušovoj, označava specifičan način "vezanosti ljudskog bića za aspolutnu meru" (Rausch, 1982: 21), kojoj čovek mora odgovoriti načinom držanja vlastitog bića što ga obavezuje na određeni način postupanja. Kao drugo, stupanje u odnos sa onim božanskim određeno je s obzirom

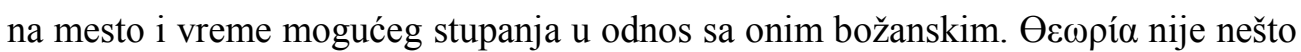
što se događa svakog trena, već je događaj koji je lokalan i individualan (Rausch, 1982: 24). Dati događaj svakako određuje ponavljanje, ali pri tome ponavljanje ne bi trebalo misliti kao puko opetovanje svečanosti, već kao sam način vremenovanja svetkovine, kao vremenitost božanskog samoprikazivanja.

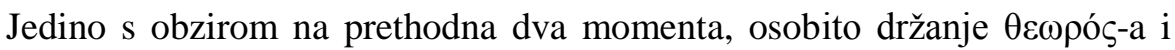
boravljenje unutar specifičnog područja svetkovine koju odlikuje poseban tip

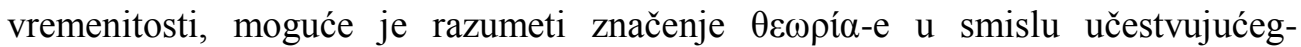
posmatranja. Prethodno ne treba razumeti kao "subjektivnu" i "objektivnu" stranu $\theta \varepsilon \omega \rho i ́ \alpha-e$, jer je iskustvo $\theta \varepsilon \omega \rho i ́ \alpha-e$ sušta suprotnost razlike subjekt-objekt. Posmatranje na koje cilja $\theta \varepsilon \omega \rho i ́ \alpha$ nije ni objektivnost modernog naučnog držanja, niti puko posmatranje nečega pojedinačnog što se događa pred posmatračem.

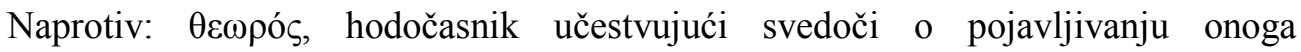

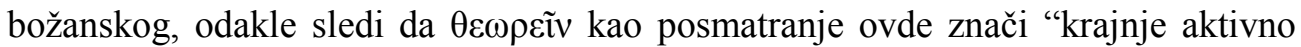
učestvovanje" (Rausch, 1982: 22), analogno učestvovanju u pozorišnoj predstavi koja za stare Grke nikada nije bila daleko od kultne radnje. No, kao što ćemo videti u onom što sledi, "ekstremna aktivnost učestvovanja" o kojoj govori Raušova zapravo je radikalna pasivnost koju sa sobom nosi teorijsko držanje.

Razumevanje $\theta \varepsilon \omega \rho i ́ \alpha$-e kao iskustva radikalnog učestvovanja koje

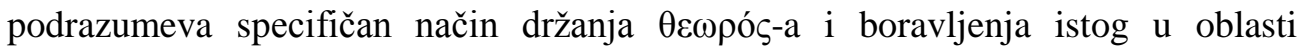
svetkovine kao regije samopojavljivanja onoga božanskog posebno razvija HansGeorg Gadamer u delu Istina i metoda. Gadamer polazi od toga da mi govorimo o slavljenju, odvijanju slavlja, tj. da govorimo o tome da učestvujemo u svečanosti. Odvijanje svečanosti kao njeno izvršenje je time specifičan oblik ponašanja. Međutim, izvršenje svečanosti, smatra Gadamer, ne podrazumeva nikakav cilj koji treba postići. Slaviti kao izvršiti ne znači postaviti nekakav cilj ka kome treba težiti, jer kada izvršavamo ili izvodimo svečanost, cilj je uvek već tu (Gadamer, 1978: 
151). Sa druge strane, primećuje Gadamer, očigledno je da svečanosti i praznici jesu nešto što opstoji tako što se ponavlja. Dakle, praznik jeste nešto što se vraća, ili jeste na način vraćanja (Gadamer, 1978: 152). Gadamer ističe da ponavljanje svečanosti ne bi trebalo misliti kao vraćanje nečega što je prethodno bilo, niti je ovde na delu puko sećanje prve, tj. "izvorne" svečanosti: "Prvotni sakralni karakter svih svečanosti očigledno isključuje razlikovanja kakva su nam poznata u iskustvu vremena sadašnjosti, u sećanju i očekivanju. Ovo iskustvo vremena svečanosti je, naprotiv, odvijanje, jedna sadašnjost sui generis" (Gadamer, 1978: 154).

U potpunom saglasju sa Gadamerovim analizama, Raušova ukazuje na poseban oblik vremena koji karakteriše svečanost kao odlikovani oblik fenomena teorije, a što se razlikuje od uobičajenog razumevanja vremena. Vreme svečanosti, po Raušovoj, jeste događaj unutar kojeg sveto vreme božanskog prisustva prodire $\mathrm{u}$ profano vreme i gde ritam svečanosti predstavlja ritmičku obnovu samog vremena (Rausch, 1982: 29). Gadamer drži da mi ne razumemo svečanost kao onu koja se ponavlja zato što joj možemo odrediti neko vreme kada se odigrava. Naprotiv, vreme u kojem se događa svečanost javlja se samo kroz vraćanje i ponavljanje samog slavlja. Takvo vreme svečanosti svedoči o primatu nečega što se događa $u$ njemu pripadnom vremenu ili u "pravo vreme", tj. svedoči o nečemu što se događa sa one strane vremena koje se može računati.

Svečanost Gadamer određuje faktom da je ona za onoga koji je slavi $t u$, analogno pozorištu gde je posmatrač određen onim biti-tu. Biti-tu ne označava bezinteresno posmatranje, niti puku činjenicu da je neko saprisutan nečemu drugom što prosto posmatra, već, slično kao kod Raušove, po Gadameru: "Biti-tu znači sudelovanje" (Gadamer, 1978: 154). Da bi se znalo kako nešto jeste, mora se istom biti sa-prisutan. Rečju, samo učestvujući može se znati, tj. samo učestvujući može

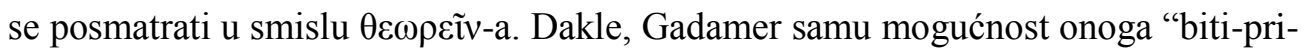
stvari” izvodi iz onoga biti-tu, sudelovati u događanju samopojavljivanja bića ili onoga božanskog. Biti-tu događaja svečanosti određuje ono "biti-pri-stvari" svečanosti, biti određen onim što se odigrava pri svečanosti. Rečju, sama svečanost jeste ona koja omogućava da se pri njoj bude tako što se u njoj učestvuje. Gadamer dato iskustvo svečanosti i njemu primerenu vremenitost gradi upravo pozivajući se na prvobitni smisao starogrčke reči $\theta \varepsilon \omega \rho i ́ \alpha$ :

Posmatranje je, dakle, pravi način sudelovanja... Sudeonici jednog svečanog

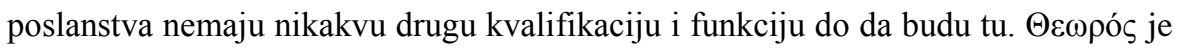
posmatrač, dakle, u pravom smislu te reči, onaj koji u svečanom aktu sudeluje tim biti-tu i time dobija svoju sakralno-pravnu odliku, tj. svoju nepovredivost (Gadamer, 1978: 154). 
Polazeći od načina na koji svečanost jeste, Gadamer ističe da biti-tu učesnika zapravo znači biti-izvan-sebe. Ovaj bitak-izvan-sebe koji odlikuje svečanost, ne treba prosto razumeti kao nešto negativno, kao gubljenje sebe. Naprotiv, bitak-izvan-sebe što ga odlikuje svečanost zapravo treba razumeti kao “pozitivnu mogućnost, sasvim biti pri nečemu prisutan” (Gadamer, 1978: 155). Biti-tu kao biti-izvan-sebe Gadamer razume kao samozaboravljanje u smislu predavanja onome što se prikazuje, tj. izlaženje iz kruga privatnosti, naviknutosti na određeni način života i mišljenja i dopuštanje da se bude određen onim drugim. Dakle, posmatranje prisutno unutar teorije znači napuštanje privatnosti i izlazak u susret samoprikazivanju same stvari. Dato napuštanje ne znači gubljenje sebe u nečemu što je interesantno, niti žudnju za pukom novinom koja odlikuje znatiželju, već znači pustiti da nam se sama stvar sobom pokaže (Gadamer, 1978: 156).

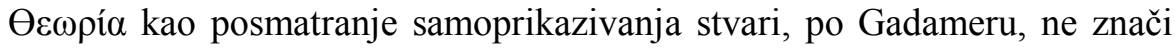
posmatranje nekog pojedinačnog predmeta: "Contemplatio se ne zadržava kod

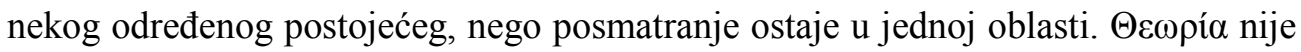
toliko pojedinačni trenutni akt posmatranja koliko držanje, položaj u kojem stojimo" (Gadamer, 1996: 21). Nasuprot našoj uobičajenoj upotrebi pojmova uma i teorije, Gadamer ističe da ovi pojmovi izvorno ne upućuju na sposobnosti subjekta, na nešto što pripada subjektu kao takvom u smislu njegovih svojstava. Dakle, $\theta \varepsilon \omega \rho i ́ \alpha$ nije puko svojstvo subjekta, već je, upravo suprotno tome, mišljena polazeći od onoga što subjekt posmatra: "Theoria je zbiljsko učešće, dakle nije nikakav čin,

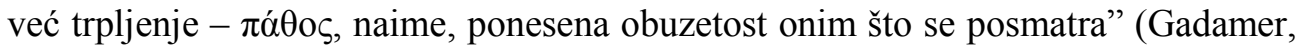
1978: 154).

Kao što smo već istakli, teorija se odlikuje određenim načinom držanja

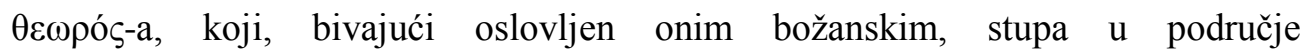
samozaboravnog predavanja prizoru bića (Gadamer, 1996: 25). ${ }^{5}$ Teorija je time izvorna praksa koju odlikuje ekstatičko iskušavanje samopojavljivanja bića.

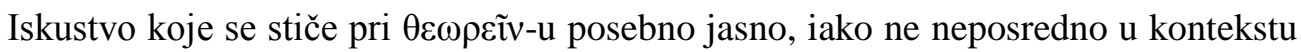
razmatranja $\theta \varepsilon \omega \rho i ́ \alpha-e$, određuje Hajdeger:

Steći iskustvo o nečemu - svejedno da li je u pitanju stvar, čovek ili bog - znači da nam se to dogodi, da nas pogodi, da nas obuzme, da nas obori i preobrazi. Kada govorimo o 'sticanju' iskustva, to ne znači da je iskustvo naša tvorevina; steći u

\footnotetext{
${ }^{5} \mathrm{U}$ "Pohvali teoriji” Gadamer određuje prirodu teorijske prakse kao one koja upućuje preko sebe: "Neobraziranje na sebe, obaziranje na ono što jeste; to je vrsta obrazovane, skoro da bih mogao da kažem, božanske svesti" (Gadamer, 1996: 25).
} 
'steći iskustvo' znači: preturiti preko glave, pretrpeti, primiti ono što nas pogađa tako što ćemo se tome potčiniti (Hajdeger, 2007: 155).

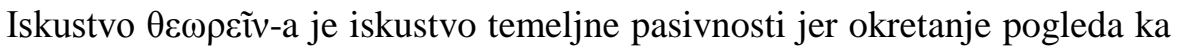
prizoru same stvari dolazi od prethodne oslovljenosti samim prizorom i puštanja da

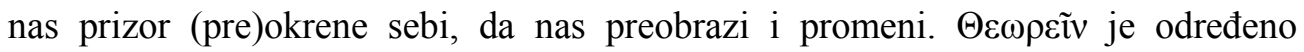
pojavljivanjem boga, ali bog se ne pojavljuje bilo kom, već samo plemenitom: "Viđenje boga ima odliku preobražaja. Ono uzdiže ljudsko biće i mera je njegove vrednosti (veličine, beznačajnosti). Biti plemenit, odnosno imati određeno držanje, određeni etos, preduslov je viđenja" (Rausch, 1982: 31) Međutim, plemenitost nije nešto što uzrokuje viđenje boga, već se plemenitost, ističe Raušova, određuje polazeći od samog bogojavljanja. Prisutnost boga unutar prostor-vremena $\theta \varepsilon \omega \rho i ́ \alpha-e$ koja uzrokuje preobražaj $\theta \varepsilon \omega \rho o ́ \varsigma-a$, po Raušovoj, dvostruko je vezana za sam fenomen posmatranja. Prvo, data tranformacija pojavljuje se kao otvaranje vidljivosti pojedinačnih stvari i prirode u celini i, kao drugo, ona je otvaranje viđenja samom čoveku, a oba momenta se događaju kao posmatranje boga unutar svetog prostor-vremena svečanosti (Rausch, 1982: 32).

Ako praksa posmatranja, kao otvorenost pogleda za ono što jeste, počiva na zovu onoga božanskog koji otvara boravište unutar kojeg se posmatranje jedino može nastaniti, tada posmatrati ono božansko zapravo znači biti posmatran od strane onog božanskog. Posmatranje koje karakteriše $\theta \varepsilon \omega p i ́ \alpha-u$ je posmatranje posebne vrste koje Jaš Elsner naziva i "ritualno-orijentisanim viđenjem" (Elsner, 2000: 46) i što podrazumeva ritualni proces oslobađanja od svih socijalnih i diskurzivnih stega kako bi vernik stupio u područje božanskog pogleda. Elsner ističe da se unutar "ritualno-orijentisane vizuelnosti" ne može izolovati čisti momenat uzvraćanja pogleda posmatraču od strane božanskog, već da je ovde ključno "putovanje kako bi prizor mogao da uzvrati pogled" (Elsner, 2000: 61). Pored prethodnog, "ritualno-orijentisano viđenje" ima karakter susreta, dakle ono nije svodivo na svoje pojedinačne momente, ono ima oblik zajedničarenja. Dakle, unutar područja teorije, posmatrač stupa u božiji svet i božanstvo neposredno prodire u posmatračev svet: "Obostrani pogled ove vizuelnosti vrsta je epifanijskog ispunjenja, ujedno i hodočasnika-posmatrača koji otkriva svoj najdublji identitet $u$ prisutnosti boga i boga samog koji u procesu hodočasničke ceremonije prima darove i poštovanje koje je u skladu sa njegovom božanstvenošću" (Elsner, 2000: $61)$. 
Radikalna transformacija prvobitnog smisla teorije počinje sa Platonovom aproprijacijom mnogostrukog javljanja teorijskog fenomena. ${ }^{6}$ Međutim, iako je religiozno-politički smisao teorije koja podrazumeva hodočašće zarad posmatranja svetkovine glavni oblik unutar kojeg Platon nastoji da upiše novo filozofsko značenje, on nije jedini koji biva transformisan Platonovim mišljenjem. Tek ukoliko se ima u vidu svo bogastvo teorijskog fenomena, moguće je razumeti razliku Platonovog određenja teorijskog npr. u Fedonu, Fedru ili Gozbi u odnosu na Državu i Zakone. Dok Fedon i Fedar odgovaraju modelu "privatne" ili individualne

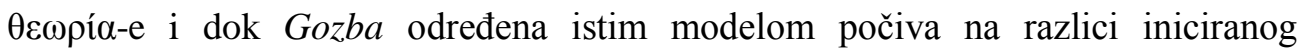
(Diotima) i neiniciranog (Sokrat) u misterije, Država i Zakoni tematizuju "civilni" model $\theta \varepsilon \omega \rho i ́ \alpha-e$.

Tačnije, Država eksplicitno tematizuje napetost "privatnog" (filozofskosokratovskog) i "civilnog" modela, tj. sukobljava ih sa ciljem mogućnosti njihovog pomirenja unutar skice idealnog polisa. Datu napetost najbolje oslikava tzv. mit o

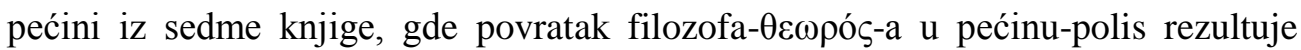
njegovim ismevanjem i eventualnom smrću. Odlazak filozofa iz sveta u kojem živi, kao odlazak od onoga poznatog zarad viđenja istine, za filozofiju nakon Platona uvek ostavlja otvorenim pitanje mogućnosti povratka datom svetu (Nightingale, 2004: 70). Iako sebe filozof najčešće vidi kao najdostojnijeg teorijskog putovanja, iako bi filozof hteo da iz onoga najudaljenijeg slavi istinu sveta u kojem boravi, njegovo viđenje i prenošenje božanskih reči uvek ostaje otvoreno za smeh i ostrakizam. ${ }^{7}$ Rečju, filozofska aproprijacija religiozno-političkog smisla teorije kao poslanstva u svrhu posmatranja istine biva određena napetošću sveta iz kojeg filozof polazi na hodočašće i istine sa kojom se vraća. Novi smisao teorije temeljno je određen nemogućnošću da se zatvori krug teorijskog putovanja i predstavlja uspostavljanje novog smisla teorijskog kao razlike filozofskog pogleda u nebo koji vodi padu u bunar i smeha tračke žene koja posmatra filozofa, o čemu Platon govori u Teetetu. Dalja povest teorije je, kako pokazuje Hans Blumenberg, upravo povest date anegdote koju prenosi Platon, gde je otuđeni filozof-teoretičar reflektovan smehom praćenim posmatranjem posmatrača (Blumenberg, 1987: 10).

6 Najbolji primer Platonovog obacivanja tradicionalnog smisla teorije i postavljanja filozofije kao istinske teorije predstavlja epizoda neodlaženja na večernju $\theta \varepsilon \omega \rho i ́ \alpha-u$ u prvoj knjizi Države i vođenje filozofskog dijaloga kao događanja same $\theta \varepsilon \omega \rho i ́ \alpha$-e u novom smislu.

${ }^{7}$ Pored prethodnog, čini se da od vremena Platona teorijski pogled filozofa nema sigurnost uzvraćanja pogleda od strane onoga božanskog, tj. da ne raspolaže izvesnošću da se ta dva pogleda sjedinjuju kao što je to slučaj u izvornom smisla $\theta \varepsilon \omega \rho \varepsilon \tilde{v} v-a$ (Gasché, 2007: 207). 
Nikola Tatalović

\section{BASIC CHARACTERISTICS OF PRE-PHILOSOPHICAL EXPERIENCE OF THEORY}

\section{Summary}

This paper is about the basic characteristics of the pre-philosophical experience of theory. The paper shows that the original meaning of theory is inseparable from its religiouspolitical context, and that the later philosophical meaning of theory appears as a transformation of the original meaning of theory as a pilgrimage aimed at observing the festival. Within the religious-political context, the paper shows the original experience of theory in its threefold structure: leaving the known world (polis), traveling and observing the divine, and returning to the known world. The analysis shows that the experience of theory as a specific journey abroad implies a certain attitude of the observer - a certain ethos, and that viewing itself actually means staying within the region of the appearance of the divine that transforms the observer.

Keywords: theory, festival, pilgrimage, viewing, experience, god

\section{LITERATURA}

Blumenberg, H. (1987). Das Lachen der Thrakerin. Eine Urgeschichte der Theorie. Frankfurt am Main: Suhrkamp.

Elsner, J. (2000). Between Mimesis and Divine Power. Visuality in the GrecoRoman World. U: Nelson, R. S. (ured.) (2000). Visuality Before and Beyond the Renaissance. Seeing as Others Saw. Cambridge: Cambridge University Press. 45-66.

Elsner, J.-Rutherford, I. (2005). Introduction. U: Elsner, J.-Rutherford, I. (ured.) (2005). Pilgrimage in Graeco-Roman and Early Christian Antiquity. Seeing the Gods. New York: Oxford University Press. 1-40.

Gadamer, H.-G. (1978), Istina i metoda. Sarajevo: Veselin Masleša.

Gadamer, H.-G. (1996). Pohvala teoriji. Podgorica: Oktoih.

Gasché, R. (2007). The Honor of Thinking: Critique, Theory, Philosophy, Stanford: Stanford University Press.

Goldhill, S. (1987). The Great Dionysia and Civic Ideology. The Journal of Hellenic Studies, 107, 58-76.

Hajdeger, M. (1999). Nauka i razmišljanje. U: Predavanja i rasprave. Beograd: Plato. 33-52.

Hajdeger, M. (2007). Suština jezika. U: Na putu k jeziku, Beograd: Fedon. 155-216. Heidegger, M. (1992). Platon: Sophistes. U: GA 19. Frankfurt am Main: Vittorio Klostermann. 
Ker, J. (2000). Solon's 'Theôria' and the End of the City. Classical Antiquity, 19, 304-329.

Koller, H. (1958). Theoros und theoria. Glotta, 36, 273-286.

Kowalzig, B. (2005). Mapping out Communitas: Performances of Theoria in Their Sacred and Political Context, U: Elsner, J.-Rutherford, J. (ured.) (2005). Pilgrimage in Graeco-Roman and Early Christian Antiquity. Seeing the Gods. New York: Oxford University Press. 41-72.

Montiglio, S. (2005). Wandering in Ancient Greek Culture. Chicago: The University of Chicago Press.

Nightingale, A. (2004). Spectacles of Truth in Classical Greek Philosophy. Theoria in Its Cultural Context. New York: Cambridge University Press.

Rausch, H. (1982). Theoria. Von ihrer sakralen zur philosophischen Bedeutung. München: Wilhelm Fink Verlag.

Rutherford, I. (2013). State Pilgrims and Sacred Observers in Ancient Greece. New York: Cambridge University Press.

Steiner, D. T. (2001). Images in Mind. Statues in Archaic and Classical Greek Literature and Thought. Princeton: Princeton University Press. 